\title{
Elaboration of the Methodology for Assessing the Development of Managerial Competences in University Students Taught with the Use of Case-Technologies
}

\author{
Natalia A. Zaitseva ${ }^{1 *}$, Anna A. Larionova ${ }^{2}$, Zhanna V. Gornostaeva ${ }^{3}$, Olga Yu. Malinina ${ }^{3}$, \\ Victoria A. Povalayeva ${ }^{3}$, Sergey L. Vasenev ${ }^{3}$, Irina A. Skrynnikova ${ }^{3}$, Alpay Ersozlu ${ }^{4}$ \\ ${ }^{1}$ Plekhanov Russian University of Economics, RUSSIA \\ 2 Financial University under the Government of the Russian Federation, RUSSIA \\ ${ }^{3}$ Institute of Service and Business (branch) Don State Technical University in Shakhty, RUSSIA \\ ${ }^{4}$ Graduate School of Education, The University of Western Australia, Nedlands, WA, AUSTRALIA
}

Received 21 June 2017 • Revised 25 August 2017 • Accepted 25 September 2017

\begin{abstract}
The purpose of this paper lies in elaborating the methodology for assessing the development of managerial competences trained with the use of case technology as one of the inherent educational technologies. The principle research method is the pedagogical experiment with three control groups of students; the authors also applied the methods of systematization and generalization of the obtained data, expert assessment and interpretation of the study results, which helped to elaborate and test the scientific and methodological tools for assessing the development of students' managerial competence. The experiment involved 68 students of the Master's Degree program in Hospitality, 2040 assessments of competence levels were performed. Results: The paper reveals the essence of the methodology for assessing the development of managerial competences in university students taught with the use of case-technologies. The authors present their own rating scale for assessing the development of the managerial competences indicated in the professional standard for "Head/Manager of hotel complex/hotel chain" in Master's Degree students majoring in Hospitality. The results prove the effectiveness of using case-technologies for developing students' managerial competence, the effectiveness of different types of cases (creative, structured, and unstructured) is specified. The challenges of using case-technologies are identified, and recommendations for their use are suggested. The methodology for assessing the development of managerial competences in university students taught with the use of case-technologies elaborated by the authors can be used in educational programs in different fields of the Humanities. The difference of this methodology from the existing ones lies in its orientation at both the educational standards and the professional standards for heads of enterprises which emerged in Russia in the past 5 years. The effectiveness of the proposed methodology has been proved by high correlation of the research results obtained in different institutions and by different experts - University professors and employers.
\end{abstract}

Keywords: managerial competence, educational technology, the level of competencies development, professional standard, case-technologies

(C) Authors. Terms and conditions of Creative Commons Attribution 4.0 International (CC BY 4.0) apply. $\triangle$ zaitseva-itig@mail.ru (*Correspondence) $\square$ annla@list.ru $\boldsymbol{B}$ zh.gornostaeva@mail.ru

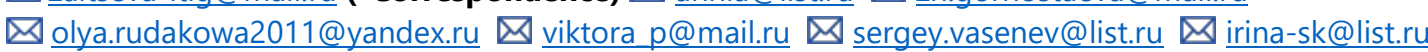




\section{Contribution of this paper to the literature}

- The author's scale of formation level assessment of the students obtaining Master's Degree in Hospitality Industry, managerial skills as reflected in the professional standard "Manager / Manager of the hotel complex / hotel chain" is suggested.

- Practice-oriented approach that allows to identify and rank the competencies, the most significant in terms of the employer in a specific region is developed.

- Main areas of assessment methods of managerial skills formation, educated with one of the inherent educational technologies - case-technologies that is tested by the authors in the course of the intermediate or final certification of students obtaining Master's degree at universities are described.

- According to the results of the pedagogical experiment the effectiveness of the use of different case studies types on the management competencies of students obtaining the Master's degree in Hospitality Industry.

- The major shortcomings and recommendations for improving the use of case-based technologies for the managerial skills formation among students getting education in Hospitality are determined.

\section{INTRODUCTION}

\section{Relevance of the Problem}

There are plenty of researches with a goal to study the most effective educational technologies, which contribute to the formation of the university students' competencies. These competencies will ensure the demand for graduates in the labor market and, consequently, will increase of the university's competitiveness in the market of educational services (Anischeva, 2006; Panfilova, 2003; Anufrieva \& Tsarev, 2016; Ezechil, Olkhovaya et al., 2013; Lebedeva, 2012, Sorikhina, 2015; Krasikova, 2007; Romanovtseva, 2016; Chen et al., 2017; Song et al., 2017; Caj et al., 2017; Shen et al., 2017). At the same time, the relevance of graduates depends on the extent to which their competence meets the requirements of employers.

In recent years, Russia has done much to determine requirements of employers to the learning results at the university in the course of educational standards development in areas of training, in order to increase the professional level of graduates and, consequently, the competitiveness of industry and service enterprises (Malysheva, 2016). However, for many years there was a problem employers did not formalize their requirements. Starting from 2013 in Russia, professional standards of occupational activities are established on the federal level, the regulations of which were taken into account in the new federal educational standards of new generation, implemented in universities since 2016.

Along with this, such changes in the development of educational standards have not solved all the existing problems from the point of view of the whole variety of professional standards requirements (Mironova et al., 2017). For example, as it will be seen from the article material, the professional standard "Manager / Manager of the hotel complex / hotel chain" for director level provides education not lower than Master's degree, which is why the pedagogical experiment was conducted in a group of students obtaining Master's degree in Hospitality Industry. In this case, this professional standard provides 16 competencies and educational standards - five in total - one competence in terms of professional competence: technology, management, quality, marketing, economics. It can be explained by the unified pattern of federal educational standards development approved by the Ministry of Education and Science in Russian Federation.

Thus, the question arises of how within the existing educational standards of higher education all the competencies specified in the relevant professional standards can be taken into account in the educational process, and how to ensure the formation of these competencies. Therefore, two issues come forward: what educational technologies should be used to provide training that will be required by the labor market, and how to assess the achievement of the goal - the level of competencies development that according to employers must be obtained by university graduates (Vasileva, 2015; Yumatov et al, 2017; Golubkova, Masalimova \& Bírová, 2017; Khrulyova \& Sakhieva, 2017; Valeeva \& Gafurov, 2017).

Thus, it is obvious that there is a number of unresolved issues with the choice of intensive types of educational technology for managerial competencies that students form while obtaining Master's degree and with the assessment of the administrative competence formation level is reflected in the professional standard. To solve these problems we implemented the study based on the example of the Hospitality Industry specialty (Master's degree). 

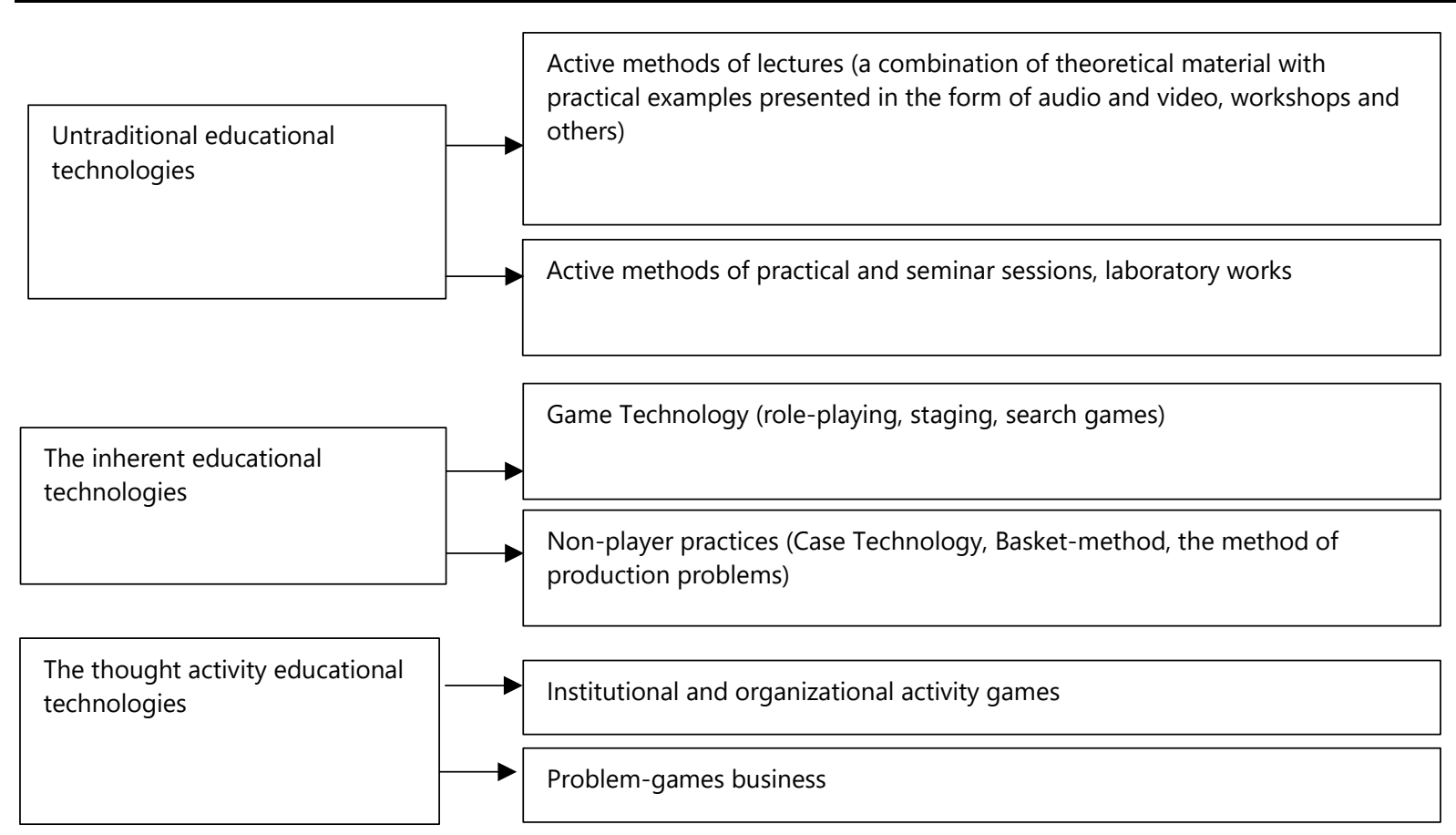

Figure 1. Classification of intensive educational technologies recommended for use in high schools, in the formation of managerial skills

\section{Goals and Objectives of the Study}

The aim of the research is to develop assessment methodology for the managerial competencies formation of university students using case-based technologies. The main objectives are: identification of the most successful educational technology recommended for use in high schools, during the formation of management skills; ranking based on the use of the expert method of managerial competencies, reflected in the professional standard "Manager / Manager of the hotel complex / hotel network"; level assessment of the five most important administrative competencies formation from the point of view of experts among students obtaining Master's degree in hospitality industry; generalization of the results obtained and effectiveness substantiation of the use of different case types to improve the level of the formation of selected managerial competencies; identification of major gaps and develop recommendations to improve the use of case management techniques for the formation of competences for students obtaining Master's degree in hospitality industry.

\section{LITERATURE REVIEW}

\section{Analysis of Russian Scientific and Pedagogical Literature}

The organizational and managerial competences formation among future graduates in modern conditions is possible only in the conditions of active and interactive learning forms; student-centered nature of education; professional and pedagogical conditions that are disclosed in the developing block -modular approach to training; organizational and methodological conditions that differ in innovative content of specialized disciplines; the introduction of an individual typological route; quasiprofessional activities; pedagogical conditions of technical support in the formation of professional skills (Krasikov, 2016; Nikitina, 2015).

B. N. Gerasimov (2009) gave the multi-criteria classification of intensive types of educational technologies recommended for managerial competencies formation for future professionals. Based on this classification, we can distinguish three big groups of intensive educational technologies (Figure 1).

The authors implemented the effectiveness evaluation of educational case technology. Let us consider it in detail.

Case technologies are a group of educational technologies consisting of methods of training based on solving specific situations. A. M. Derkach (2010) notes that case-technology are related to non-gaming simulation active learning technologies, integrating a form of developmental education and individual, group and collective activities. 
Case method (variants of the name: the method of case studies, case study, the method of specific situations, situation analysis method) is a set of methods and techniques for use in the educational process of real situations (social, human, legal, financial, economic, business situations and other) (Zaitseva et al, 2017; Platonova et al, 2016).

According to L. I. Turik (2012) the difference between the case and a business game, that provides an abstract situation, lies in the fact that the cases describe real situations occurred in specific enterprises of service and tourism (to be precise, in a case it may be a discharge from an actual situation, but still the description in the case should be as close to reality as possible).

Analysis of the available scientific literature on the use of case-based technologies in teaching university students led to the conclusion that several kinds of cases are usually used in the learning process.

1. Creative, pioneering cases - various cases (from the shortest (1-5 sentences) to long (up to 20 or more pages) describing different situations in real business. These cases can be used to estimate the variability and creative thinking of a person, his other personal competences. In individual work, it is recommended to use very short cases that allow assessing the student's presence of certain personal characteristics. When using creative cases in the group form of work with students the ability of a student when working in a team is analyzed to highlight the most creative idea, develop it and improve it, and competently present.

2. Structured cases - description of real situations (one or more correct answers are usually given in such cases) that allows analyzing the student's ability to correctly select the right answer. Properly drawn up structured case, in contrast to the creative, must contain a detailed description of the situation, including an indication of the company name, the time when the situation occurred, and so on. However, the purpose of using such cases is to assess how the so-called hard skills, i.e., a set of specific methods, tools, techniques, rules and regulations (in the hotel business - service standards) are used in certain conditions.

3. Unstructured cases - a description of the actual situation that occurred at a particular enterprise, containing, as a rule, several storylines: market conditions (the behavior of competitors, customer peculiarities, etc...), the behavior of the head, the team as a whole and the individual employees. A feature of this type of case is that they do not have the right decision in accordance with the law or any other legal documents. Students can offer and justify several solutions. The teacher or students playing the expert roles will evaluate these solutions according to the assignments indicated by the teacher. This kind of cases is directed to the formation of so-called soft skills - flexible skills necessary to the Director of the enterprise.

For self-study cases from the practice of real companies, you can use two options (Tambovkina \& Krakovskaya, 2013; Tatur, 2004):

1. The traditional approach - the use of primary information, through interviews with employees and managers of specific industries, the development of cases on this basis, aligning them with company management. It is clear that this is a more difficult path, but more effective, because the teacher can get complete information about the situation from the participants themselves.

2. Adapted approach - the use of various secondary information (articles about the enterprise in the press, on the company's website, video clips about the company, interviews with management, etc.).

It is clear that the first approach cannot always be realized in high school for two reasons: firstly, not all teachers have self-development case studies skills, and secondly, business leaders are reluctant to contact and share information about their mistakes or difficult situations, considering confidentiality of information.

In general, the analysis of publications by Russian scientists allows us to conclude that there is a large number of intensive educational technologies recommended for use in high schools, in the process of management competencies, among which the authors paid special attention to case-technologies.

\section{Analysis of Foreign Studies}

L. Ezechil (2013) points out the need to review the example of education in Romania and its learning outcomes assessment strategies. In this regard, she offers a new concept of exams organized at the end of the license and / or master's studies as a basis for the establishment of coherent criteria required in the process of certification training. Particular attention is paid to the specific management of each decision on the development of educational programs from a strategic point of view of the correlation problem and teachers' efforts coordination involved in the implementation of educational programs.

In the foreign literature, the aspects of the case technology use is widely reported in student learning. L.F.S. Minniti et al. (2017). The study of the teaching methodology with case method in Brazil notes that this method contributes to the development of critical thinking, promotes and encourages teachers and students to interact in solving practical problems of a particular company, industry.

We should also take into account the high development level of employer requirements records in the field of managerial skills among students studying hospitality programs. Thus B.J. Gray et al. (2007) note that education should be focused on preparing students for future management roles, but not only their first job, and it is 
imperative that hospitality education programs reflect the currently available managerial knowledge and skills among employers.

For a number of years authors D. V. Tesone \& P. Ricci (2005) publish the results of research conducted in Central Florida in the field of hospitality and tourism management practices that introduce the results of desired knowledge perception, skills and employers attitude, as well as their general impressions regarding the level of educational programs graduates preparation for positions at the primary level in the industry. The above authors present conclusions and proposals for joint initiatives in Florida, aimed at improving training for those from middle and high schools for a successful start in the hospitality and tourism industry.

M. Millar, Z. Mao \& P. Moreo (2010) also conducted a study to assess the discrepancies, if any, in the areas of competence, which are taught in the classroom for students of hospitality and tourism training programs, in comparison to what employers consider most important competencies for learning. The above researchers conducted personal interviews with teachers and with industry experts. The results included in the model of competency domains indicate that there are small gaps between experts and teachers in both sectors because there are difficulties in the organization of open communications between educators and professionals.

The study of L. Jiang \& the G. Alexakis (2017) provides an overview of competencies that have been identified by the leaders of the hospitality industry for the success of the work in this field for many years and the similarities, as well as the key changes in the skills required for students graduating from hotel management program.

However, it should be noted according to the paper by M. Johanson et al. (2011) very few published studies in the literature evaluated hospitality skills and key competencies, based solely on industry requirements and criticism of learning outcomes in higher education institutions in research management disciplines remains a worldwide trend (Jackson \& Chapman, 2012).

Thus, review of foreign scientific and methodical publications also confirms the relevance of this study and the lack of scientifically sound and tested in practice evaluative - diagnostic tools for managerial skills formation (Lizunkov et al, 2015; Raven, 2000), as reflected in the professional standards of business leaders in different fields, among students, trainees, using case-based technologies.

\section{MATERIALS AND METHODS}

\section{Theoretical and Empirical Methods}

To test the hypothesis of a complex we used a variety of methods, complementing each other:

- theoretical - analysis of scientific, theoretical and practical materials by specialists on issues of managerial skills formation assessment, the use of case technology, as well as professional applications in education , on the basis of which the hypothesis of research is determined; theoretical foundation and the scientific and methodological tools were developed for evaluating formation of managerial competencies of university students ;

- empirical - observation, ascertaining and forming pedagogical experiment, methods of ordering and generalization of the data, standardized interviews, expert opinions, coordination of expert assessments, interpretation of research results.

\section{Basis of the Study}

The study was based on the Plekhanov Russian University of Economics (Moscow). Assessment of the managerial competencies formation level is implemented for 68 students training areas of Hospitality Industry (Master's degree) of the following groups: 190D-m14GD / 14 (9 persons), 190D-m14GD / 15 (27 persons), 190Dm02GD / 16 (32 people).

\section{Stages of study}

The study was conducted in three phases:

In the first stage assessment of the formation of the above five managerial skills was implemented among students enrolled in the direction "Hotel Management" (Master's level) at the Plekhanov Russian University of Economics (Moscow) and testing of research topics at the initial stage of ascertaining experiment.

In the second phase, theoretical concept of study was adjusted and corrected, case studies were developed and used with the aim to the competences formation elected to perform the pedagogical experiment. At the end of the second stage the estimation of the above managerial competencies formation competences was carried out for two expert groups - employers and representatives of the university. 
In the third stage, we conducted an analysis, compilation, systematization and interpretation of data obtained from the experts accompanied by performances of the authors of articles in scientific conferences and scientificmethodical activities on the improvement of university students training quality in accordance with the employer requirements.

\section{Evaluation Criteria}

The skills requirements of the hotel enterprise manager (director), reflected in the professional standard "Manager / Manager of the hotel complex / hotel chain" were taken as a valued managerial competence. In this study, 8 experts were interviewed, including 50\% - managers of hotel business (from the head of department to the director of the hotel) in Moscow and 50\% - university professors, who did not participate in the training of students assessed, but having experience in teaching disciplines in Hospitality Industry. In the course of this survey expert opinion was given on the significance of competencies specified in the professional standard "Supervisor / manager of the hotel complex / hotel chain". Expert task was assessing the importance of the directors' hotel management competencies specified in this professional standard. The more a score of each competency, the more significant given competence for the director of the hotel is.

Assessment of the degree of consistency of expert opinion was held by computing the concordance rate (matching) according to the formula:

$$
\begin{gathered}
W=\frac{X^{2}}{m(n-1)} \\
\text { where X-squared } \\
X^{2}=\frac{12 S}{m n(n+1)}-3 m(n+1)
\end{gathered}
$$

$m$ - number of experts

$n$ - number of evaluated parameters.

$S$ - the sum of the squares of expert evaluations.

The result obtained by calculations is that $W=0.915$. Since all the parameters $W>=0.5$, then coordination of expert opinion is positive and consistent ranking can be used in practice.

Further, all 16 competencies specified in the professional standard "Manager / Manager of the hotel complex / hotel chain" were ranked according to the results of expert assessment of the competence of rank (highest rang- 1, the lowest rank - 16). The results of this phase of the study are presented in Table 1. 
Table 1. Results of a survey of experts about the importance of having the directors hotel management competencies specified in the professional standard "Manager / Manager of the hotel complex / hotel chain" (the most important - 1 least important - 16)

\begin{tabular}{|c|c|c|c|c|c|c|c|c|c|}
\hline \multirow{2}{*}{ № } & \multirow{2}{*}{ Ranked competence } & \multicolumn{7}{|c|}{ Expert number } & \multirow{2}{*}{$\begin{array}{c}\text { Agreed-valued } \\
\text { assessment of } \\
\text { competence rank }\end{array}$} \\
\hline & & 12 & 3 & 4 & 5 & 6 & 7 & 8 & \\
\hline 1 & Make decisions in unusual situations and conditions of uncertainty & 21 & 1 & 2 & 3 & 2 & 1 & 2 & 1 \\
\hline 2 & $\begin{array}{l}\text { Develop and implement projects to improve the competitiveness of the } \\
\text { hotel complex }\end{array}$ & 12 & 2 & 1 & 2 & 1 & 3 & 3 & 2 \\
\hline 3 & $\begin{array}{l}\text { Find and evaluate new market opportunities, formulate business ideas, } \\
\text { promote the development of the hotel complex }\end{array}$ & 44 & 3 & 3 & 1 & 3 & 2 & 1 & 3 \\
\hline 4 & Be skilled in identifying the problems of development of the hotel complex & 33 & 4 & 5 & 4 & 5 & 6 & 4 & 4 \\
\hline 5 & To own techniques of development of corporate and functional strategies & 98 & 5 & 6 & 5 & 4 & 4 & 5 & 5 \\
\hline 6 & $\begin{array}{l}\text { Own analysis techniques main factors determining the need for change in } \\
\text { the strategies and tactics hotel complex }\end{array}$ & 76 & 8 & 4 & 8 & 6 & 5 & 6 & 6 \\
\hline 7 & $\begin{array}{l}\text { Owning a team of management methods of the project on introduction of } \\
\text { changes in the hotel complex }\end{array}$ & 55 & 7 & 13 & 9 & 7 & 7 & 8 & 7 \\
\hline 8 & $\begin{array}{l}\text { Be skilled in planning and organization of marketing research in the } \\
\text { hospitality industry }\end{array}$ & 89 & 10 & 7 & 7 & 9 & 8 & 7 & 8 \\
\hline 9 & $\begin{array}{l}\text { Be skilled in planning and organization of marketing research in the } \\
\text { hospitality industry }\end{array}$ & 67 & 6 & 9 & 61 & & 10 & 14 & 9 \\
\hline 10 & $\begin{array}{l}\text { Use art quantification, analysis, and presentation of information on the hotel } \\
\text { product }\end{array}$ & 1110 & 9 & 8 & 10 & 8 & 9 & 10 & 10 \\
\hline 11 & $\begin{array}{l}\text { To own techniques and strategic situation analysis and evaluation of the } \\
\text { activities of the hotel complex }\end{array}$ & 1012 & 211 & 10 & & 10 & 11 & 9 & 11 \\
\hline 12 & $\begin{array}{l}\text { Possess organizational methods of diagnosis and hotel complex } \\
\text { organizational design }\end{array}$ & 1211 & 12 & 11 & 121 & 12 & 14 & 13 & 12 \\
\hline 13 & $\begin{array}{l}\text { Be skilled in organizing the strategic control and evaluation of the } \\
\text { implementation of the development strategy of the hotel complex }\end{array}$ & 1314 & 415 & 12 & 131 & 13 & 12 & 11 & 13 \\
\hline 14 & $\begin{array}{l}\text { Be skilled in creating and maintaining a database on the various indicators of } \\
\text { the hotel complex }\end{array}$ & 1613 & 313 & & & & & 12 & 14 \\
\hline 15 & $\begin{array}{l}\text { Have the skills to overcome the resistance of the collective implementation } \\
\text { of changes }\end{array}$ & 1415 & 516 & 16 & 14 & & 15 & 15 & 15 \\
\hline 16 & $\begin{array}{l}\text { Control the process of implementing changes, evaluate the effectiveness of } \\
\text { the implementation of projects }\end{array}$ & 1516 & 614 & 15 & 15 & & & 16 & 16 \\
\hline
\end{tabular}

Source: research by the author

As can be seen from this figure, in the opinion of all the experts involved in the pedagogical experiment, the five most important competencies from the point of view of experts of management competence, specified in the professional standards "Head / Manager of the hotel complex / hotel chain", are the following: ability to make decisions in unusual situations and the conditions of uncertainty; find and evaluate new market opportunities; formulate business ideas; promote the development of the hotel complex; be skilled in identifying the problems of development of the hotel complex; own methods of developing the corporate and functional strategies. Pedagogical experiment was conducted in relation to these five competencies.

\section{The Course and the Experiment Description}

The study was implemented in respect of 68 students obtaining a Master's Degree in Hotel Management at the Plekhanov Russian University of Economics (Moscow) from 2015 to 2017. Assessment of the managerial competencies formation level is carried out for the above five management competencies. To form a data management competencies three of the case of each species (creative, structured, unstructured) were developed and used in three disciplines. Thus, the total number of developed cases was 27. During the period from 2015 to 2017, 2040 level measurements of competency formation were made (Estimated level of formation of 5 managerial skills have 68 students in three disciplines before the start of the discipline, and after studying it using cases). Two groups of experts implemented measurements of the level of formation of competences: teachers of universities and employers (from the head of the service level of the hotel director). The authors analyzed and interpreted the obtained measurement results to obtain an expert efficiency assessment of the use of different case types studies on 
Table 2. Control group results in ascertaining experiment stage

\begin{tabular}{|c|c|c|c|c|c|c|c|c|c|}
\hline \multirow[b]{2}{*}{ Ranked competence } & \multicolumn{3}{|c|}{ 190D-m 14GD / 14} & \multicolumn{3}{|c|}{ 190D-m14GD / 15} & \multicolumn{3}{|c|}{ 190D-m02GD / 16} \\
\hline & low level & $\begin{array}{c}\text { an } \\
\text { average } \\
\text { level }\end{array}$ & $\begin{array}{c}\text { a high } \\
\text { level }\end{array}$ & low level & $\begin{array}{c}\text { an } \\
\text { average } \\
\text { level }\end{array}$ & $\begin{array}{l}\text { a high } \\
\text { level }\end{array}$ & low level & $\begin{array}{c}\text { an } \\
\text { average } \\
\text { level }\end{array}$ & $\begin{array}{c}\text { a high } \\
\text { level }\end{array}$ \\
\hline $\begin{array}{l}\text { isions in unusual } \\
\text { and conditions of } \\
\text { ty }\end{array}$ & $\begin{array}{c}66,67 \% \\
6 \text { persons }\end{array}$ & $\begin{array}{c}33,33 \% \\
3 \text { persons }\end{array}$ & $0 \%$ & $\begin{array}{c}63,0 \% \\
17 \\
\text { persons }\end{array}$ & $\begin{array}{c}29,6 \% \\
\text { persons }\end{array}$ & $\begin{array}{c}7,4 \% \\
2 \text { persons }\end{array}$ & $\begin{array}{c}50,0 \% \\
16 \\
\text { persons }\end{array}$ & $\begin{array}{c}34,4 \% \\
11 \\
\text { persons }\end{array}$ & $\begin{array}{c}15,6 \% \\
5 \text { persons }\end{array}$ \\
\hline $\begin{array}{l}\text { Develop and implement } \\
\text { projects to improve the } \\
\text { competitiveness of the hotel } \\
\text { complex }\end{array}$ & $\begin{array}{c}55,56 \% \\
5 \text { persons }\end{array}$ & $\begin{array}{c}33,33 \% \\
3 \text { persons }\end{array}$ & $\begin{array}{c}11,11 \% \\
1 \text { persons }\end{array}$ & $\begin{array}{c}44,4 \% \\
12 \\
\text { persons }\end{array}$ & $\begin{array}{c}40,7 \% \\
11 \\
\text { persons }\end{array}$ & $\begin{array}{c}14,8 \% \\
4 \text { persons }\end{array}$ & $\begin{array}{c}31,3 \% \\
10 \\
\text { persons. }\end{array}$ & $\begin{array}{c}40,6 \% \\
13 \\
\text { persons }\end{array}$ & $\begin{array}{c}28,1 \% \\
9 \text { persons. }\end{array}$ \\
\hline $\begin{array}{l}\text { Find and evaluate new market } \\
\text { opportunities, formulate } \\
\text { business ideas, promote the } \\
\text { development of the hotel } \\
\text { complex }\end{array}$ & $\begin{array}{c}44,44 \% \\
4 \text { persons }\end{array}$ & $\begin{array}{c}44,44 \% \\
4 \text { persons }\end{array}$ & $\begin{array}{c}11,11 \% \\
1 \text { persons }\end{array}$ & $\begin{array}{c}51,9 \% \\
14 \\
\text { persons }\end{array}$ & $\begin{array}{c}33,3 \% \\
9 \text { persons }\end{array}$ & $\begin{array}{c}14,8 \% \\
4 \text { persons }\end{array}$ & $\begin{array}{c}40,6 \% \\
13 \\
\text { persons }\end{array}$ & $\begin{array}{c}34,4 \% \\
11 \\
\text { persons }\end{array}$ & $\begin{array}{c}25,0 \% \\
8 \text { persons }\end{array}$ \\
\hline $\begin{array}{l}\text { Be skilled in identifying the } \\
\text { problems of development of } \\
\text { the hotel complex }\end{array}$ & $\begin{array}{c}66,67 \% \\
6 \text { persons }\end{array}$ & $\begin{array}{c}22,22 \% \\
2 \text { persons }\end{array}$ & $\begin{array}{c}11,11 \% \\
1 \text { persons }\end{array}$ & $\begin{array}{l}55,6 \% \\
15 \\
\text { persons }\end{array}$ & $\begin{array}{c}25,9 \% \\
7 \text { persons }\end{array}$ & $\begin{array}{c}18,5 \% \\
5 \text { persons }\end{array}$ & $\begin{array}{c}53,1 \% \\
17 \\
\text { persons }\end{array}$ & $\begin{array}{c}25,0 \% \\
8 \text { persons }\end{array}$ & $\begin{array}{c}21,9 \% \\
7 \text { persons }\end{array}$ \\
\hline $\begin{array}{l}\text { To own techniques of } \\
\text { development of corporate and } \\
\text { functional strategies }\end{array}$ & $\begin{array}{c}33,33 \% \\
3 \text { persons }\end{array}$ & $\begin{array}{c}44,44 \% \\
4 \text { persons }\end{array}$ & $\begin{array}{c}22,22 \% \\
2 \text { persons }\end{array}$ & $\begin{array}{c}40,7 \% \\
11 \\
\text { persons }\end{array}$ & $\begin{array}{c}37,0 \% \\
10 \\
\text { persons } \\
\end{array}$ & $\begin{array}{c}22,2 \% \\
6 \text { persons }\end{array}$ & $\begin{array}{c}25,0 \% \\
8 \text { persons }\end{array}$ & $\begin{array}{c}43,8 \% \\
14 \\
\text { persons } \\
\end{array}$ & $\begin{array}{l}31,3 \% \\
10 \\
\text { persons } \\
\end{array}$ \\
\hline
\end{tabular}

the management competencies among students obtaining Master's degree in Hospitality Industry. In addition, a survey of experts involved in the pedagogical experiment identified and summarized the key recommendations to improve the effectiveness of case-based technologies in the educational process.

\section{RESULTS}

\section{Ascertaining Stage of the Experiment}

Pedagogical experiment included a group of students studying at the Plekhanov Russian University of Economics master's program "Corporate Strategies industry of hospitality" direction I prepare "Hospitality" in the period from 2015 to 2017.

Cases have been developed for three disciplines: the "Corporate Management in the Hospitality Industry", "Management of the hotel staff of the enterprise", "Modern technologies of hotel business." All selected subjects studied in semester 2-3, i.e., have previous discipline, which also examines governance issues. For these disciplines three of the case of each species (creative, structured, unstructured) were developed, aimed at forming five management competencies that received grades from 1 to 5 . At the first lesson of each discipline, the formation level of the above managerial competencies was measured among students.

The following points were used to assess the level of administrative competence formation following the author's scale:

- low level - not fully own basic concepts within the evaluated competence, may fail the result in the positive examples of the work of the hotel staff having this competence, do not have the full method of decisionmaking within the analyzed competence;

- average - not a complete mastery of the basic concepts within the competence of the estimated partial knowledge of the methods of decision-making within the analyzed competence; can cause one or two positive examples of an employee of the hotel, which has this competence;

- high level - knows the specifics of the competence in the hospitality industry, mainly owned by the methods of decision-making within the analyzed competence freely oriented in the current situation in the hotel business in the framework of this competence.

In view of this scale, the mastering level was evaluated among students in three control groups by selected competence, the results of which are reflected in Table 2.

Ascertaining step of the experiment showed that as a result of the subject study by students preceding three subjects chosen for the experiment, their level of data management formation skills is low.

The group received the lowest evaluation of the development level of management competence because 33.33\% of the total number of students were students from the Republic of Syria with poor knowledge of Russian language. 


\begin{tabular}{|c|c|c|}
\hline \multirow{3}{*}{$\begin{array}{l}\text { Scientific and methodological } \\
\text { support for assessing the } \\
\text { formation of managerial } \\
\text { competencies of university } \\
\text { students trained with the use } \\
\text { of case studies }\end{array}$} & $\begin{array}{l}\text { Practical implementation of the } \\
\text { methodology using the expert method }\end{array}$ & \multirow[t]{2}{*}{$\begin{array}{l}\text { Generalization of the results } \\
\text { obtained and introduction of } \\
\text { adjustments in scientific and } \\
\text { methodological support }\end{array}$} \\
\hline & \multirow{4}{*}{$\begin{array}{l}\text { - Selection of control groups and experts } \\
\text { - Teaching or instructing teachers in the } \\
\text { methodology of application of the } \\
\text { technology case } \\
\text { - Development of case studies and their } \\
\text { use in the educational process } \\
\text { - Carrying out of measurements of level } \\
\text { of formation of administrative } \\
\text { competences at students } \\
\text { - Survey of experts on the results of their } \\
\text { participation in assessing the level of } \\
\text { competency formation among } \\
\text { students of control groups }\end{array}$} & \\
\hline & & $\begin{array}{l}\text { - Analysis of the results using } \\
\text { the concordance coefficient } \\
\text { to assess the consistency of } \\
\text { expert opinions }\end{array}$ \\
\hline \multirow{2}{*}{$\begin{array}{l}\text { - Choice of competencies } \\
\text { reflected in the professional } \\
\text { standard, most relevant for a } \\
\text { particular region } \\
\text { - Development of instructions } \\
\text { for the application of cases in } \\
\text { the teaching of students and } \\
\text { the measurement of their } \\
\text { competencies prior to the } \\
\text { beginning of the study of the } \\
\text { discipline }\end{array}$} & & $\begin{array}{l}\text { - Synthesis of the results of } \\
\text { case studies in the teaching }\end{array}$ \\
\hline & & $\begin{array}{l}\text { - Development of } \\
\text { recommendations for } \\
\text { introducing changes and } \\
\text { adjustments to the } \\
\text { methodology }\end{array}$ \\
\hline
\end{tabular}

Figure 2. Summary of evaluation methods for managerial competencies formation among university students studying Hospitality program (graduate level) using case study technology

The highest assessment in group 190D-m14GD / 15 can be explained by a high proportion (40.7\% or 11 persons) of undergraduate alumni Hospitality Industry specialty.

Despite the presence of certain features in each analyzed groups following common points can be outlined: the highest level of mastery is marked by competence "own methods of development of corporate and functional strategies", which is explained by compulsory study of these issues in undergraduate programs. The lowest level of mastery in all three control groups of two competencies "have the skills to identify the problems of development of the hotel complex" and "Making decisions in unusual situations and conditions of uncertainty."

\section{Forming Stage of the Experiment}

The purpose of the formative stage of the experiment is to form managerial competencies reflected in the professional standard Supervisor / manager of the hotel complex / hotel chain" in students enrolled in the master's program "Corporate Strategies hospitality industry" specialty of "Hospitality" at the expense of application in the educational process of actual cases.

Cases that reflect the real situation in the Russian and foreign hospitality industry, related to the organization of activities of hotels, as well as the development of their corporate strategies to address the complex situation in the field of personnel management were used in the learning process. Work with case studies was carried out in the framework of individual and group assignment in a ratio of about 50/50. Group forms of work were used mainly for solving creative and unstructured cases.

The main points of evaluation methods of managerial skills formation among students enrolled in the "Hospitality" specialty (graduate level) using case-based technologies are reflected in Figure 2.

When applying this method, it is important to take into account regional approach, since the peculiarities of the development of the hospitality industry are different in different regions, e.g. in resort areas (Crimean Republic, Krasnodar, Kaliningrad region and other). Relevant development of the spa complex based on the existing infrastructure, and hence competence associated with managing hotels, located mainly at the stage of growth and stabilization can have more value, and for the regions in which hospitality industry is still emerging, the competence of forming an exit strategy in the market of hotel services is relevant. Institution evaluates all of this on its own, based on a survey of experts from the number of employers in the region. 
Table 3. The control group results in the control stage of the experiment

\begin{tabular}{|c|c|c|c|c|c|c|c|c|c|}
\hline \multirow[b]{2}{*}{ Ranked competence } & \multicolumn{3}{|c|}{ 190D-m14GD / 14} & \multicolumn{3}{|c|}{ 190D-m 14GD / 15} & \multicolumn{3}{|c|}{ 190D-m02GD / 16} \\
\hline & low level & $\begin{array}{c}\text { an } \\
\text { average } \\
\text { level }\end{array}$ & $\begin{array}{l}\text { a high } \\
\text { level }\end{array}$ & low level & $\begin{array}{c}\text { an } \\
\text { average } \\
\text { level }\end{array}$ & $\begin{array}{l}\text { a high } \\
\text { level }\end{array}$ & low level & $\begin{array}{c}\text { an } \\
\text { average } \\
\text { level }\end{array}$ & $\begin{array}{l}\text { a high } \\
\text { level }\end{array}$ \\
\hline $\begin{array}{l}\text { Make decisions in } \\
\text { unusual situations and } \\
\text { conditions of } \\
\text { uncertainty } \\
\end{array}$ & $\begin{array}{c}22,22 \% \\
2 \text { persons }\end{array}$ & $\begin{array}{c}55,56 \% \\
5 \text { persons }\end{array}$ & $\begin{array}{c}22,22 \% \\
2 \text { persons }\end{array}$ & $\begin{array}{c}40,7 \% \\
11 \\
\text { persons }\end{array}$ & $\begin{array}{c}44,4 \% \\
12 \\
\text { persons }\end{array}$ & $\begin{array}{c}14,8 \% \\
4 \text { persons }\end{array}$ & $\begin{array}{c}34,4 ; \\
11 \\
\text { persons }\end{array}$ & $\begin{array}{c}43,8 \% \\
14 \\
\text { persons }\end{array}$ & $\begin{array}{c}21,9 \% \\
7 \text { persons }\end{array}$ \\
\hline $\begin{array}{l}\text { Develop and } \\
\text { implement projects to } \\
\text { improve the } \\
\text { competitiveness of the } \\
\text { hotel complex }\end{array}$ & $\begin{array}{c}33,33 \% \\
3 \text { persons }\end{array}$ & $\begin{array}{c}33,33 \% \\
3 \text { persons }\end{array}$ & $\begin{array}{c}33,33 \% \\
3 \text { persons }\end{array}$ & $\begin{array}{c}33,3 \% \\
9 \text { persons }\end{array}$ & $\begin{array}{c}44,4 \% \\
12 \\
\text { persons }\end{array}$ & $\begin{array}{c}22,2 \% \\
6 \text { persons }\end{array}$ & $\begin{array}{c}18,8 \% \\
6 \text { persons }\end{array}$ & $\begin{array}{c}50,0 \% \\
16 \\
\text { persons }\end{array}$ & $\begin{array}{c}31,3 \% \\
10 \\
\text { persons }\end{array}$ \\
\hline $\begin{array}{l}\text { Find and evaluate new } \\
\text { market opportunities, } \\
\text { formulate business } \\
\text { ideas, promote the } \\
\text { development of the } \\
\text { hotel complex }\end{array}$ & $\begin{array}{c}22,22 \% \\
2 \text { persons }\end{array}$ & $\begin{array}{c}44,44 \% \\
4 \text { persons }\end{array}$ & $\begin{array}{c}33,33 \% \\
3 \text { persons }\end{array}$ & $\begin{array}{c}37,0 \% \\
10 \\
\text { persons }\end{array}$ & $\begin{array}{c}37,0 \% \\
10 \\
\text { persons }\end{array}$ & $\begin{array}{c}25,9 \% \\
7 \text { persons }\end{array}$ & $\begin{array}{c}28,1 \% \\
9 \text { persons }\end{array}$ & $\begin{array}{c}31,3 \% \\
10 \\
\text { persons }\end{array}$ & $\begin{array}{l}40,6 \% \\
13 \\
\text { persons }\end{array}$ \\
\hline $\begin{array}{l}\text { Be skilled in identifying } \\
\text { the problems of } \\
\text { development of the } \\
\text { hotel complex }\end{array}$ & $\begin{array}{c}33,33 \% \\
3 \text { persons }\end{array}$ & $\begin{array}{c}33,33 \% \\
3 \text { persons }\end{array}$ & $\begin{array}{c}33,33 \% \\
3 \text { persons }\end{array}$ & $\begin{array}{c}37,0 \% \\
10 \\
\text { persons }\end{array}$ & $\begin{array}{c}33,3 \% \\
9 \text { persons }\end{array}$ & $\begin{array}{c}29,6 \% \\
8 \text { persons }\end{array}$ & $\begin{array}{c}37,5 \% \\
12 \\
\text { persons }\end{array}$ & $\begin{array}{c}31,3 \% \\
10 \\
\text { persons }\end{array}$ & $\begin{array}{c}31,3 \% \\
10 \\
\text { persons }\end{array}$ \\
\hline $\begin{array}{l}\text { To own techniques of } \\
\text { development of } \\
\text { corporate and } \\
\text { functional strategies }\end{array}$ & $\begin{array}{c}22,22 \% \\
2 \text { persons }\end{array}$ & $\begin{array}{c}33,33 \% \\
3 \text { persons }\end{array}$ & $\begin{array}{c}44,44 \% \\
4 \text { persons }\end{array}$ & $\begin{array}{c}29,6 \% \\
8 \text { persons }\end{array}$ & $\begin{array}{c}29,6 \% \\
8 \text { persons }\end{array}$ & $\begin{array}{c}29,6 \% \\
8 \text { persons }\end{array}$ & $\begin{array}{c}25,0 \% \\
8 \text { persons }\end{array}$ & $\begin{array}{c}40,6 \% \\
13 \\
\text { persons }\end{array}$ & $\begin{array}{l}43,8 \% \\
14 \\
\text { persons }\end{array}$ \\
\hline
\end{tabular}

\section{The Control Stage of the Experiment}

The control stage of pedagogical experiment was conducted in the period from 2015 (after the adoption of the professional standard "Manager / Manager of the hotel complex / hotel chain" and September 2017 inclusive), in the framework of the interim or final assessment of students on the three above-mentioned disciplines. To assess the formation of competency levels university teachers were involved with experience in teaching Hospitality program courses, as well as managers of different levels of hotels in Moscow.

At this stage, the main points of the study were corrected, the results and their generalization and systematization was analyzed and conclusions obtained in the course of an experimental study were formulated. Along with this accuracy of the experimental data was refined, obtained with statistical analysis with the use of concordance coefficient (matching) calculated by the formulas 1 and 2 .

The evaluation results of competencies mastering level among students within selected control groups at the end of the three subjects chosen for pedagogical experiment are presented in Table 3.

Comparative analysis of the data presented in Table 2 and 3 shows that by teaching students in the control groups and the use of different cases, including in the form of project work, it was possible to increase the level of competencies mastery significantly. The following competencies are improved: "Making decisions in unusual situations and conditions of uncertainty", "Develop and implement projects to improve the competitiveness of the hotel complex "," Find and evaluate new market opportunities, formulate business ideas, promote the development of the hotel complex."

As a result of the formation level measurement of the above five disciplines we made a conclusion about the effectiveness of different types of case studies on the management competencies formation among students taking course of Hospitality Industry (Master's degree) (Figure 3). 


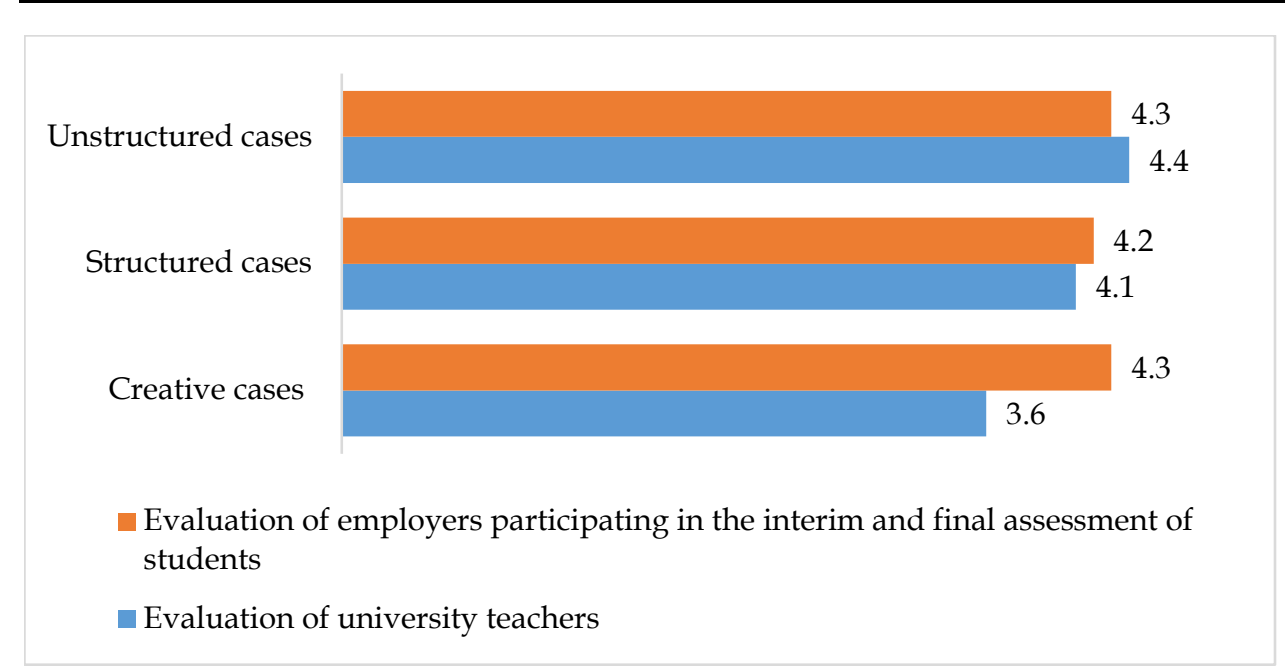

Figure 3. Expert evaluation of the effectiveness of the use of different types of case studies on the management competencies of students taking course of Hospitality Industry (Master's degree) (on the results of the pedagogical experiment)

As can be seen from the data in Figure 3, according to employers' evaluation the most effective, i.e., showed the greatest increase in the formation level of managerial competencies were unstructured cases. According to the teachers, all three cases showed approximately equal results.

According to the authors involved in the interpretation of the data, high performance employers' assessments on unstructured case studies are explained by the fact that for their solution only the cluster approach and project work in teams, including within a few sessions was used. As a result, students develop more competence such as teamwork, project management team, skills to overcome the resistance of participants in the project implementation of the changes. All this eventually increases the effectiveness of the application of unstructured cases for forming competence selected for pedagogical experiment.

In addition, survey results of experts who participated in the experiment, most frequently mentioned shortcomings in the use of case-technology for the formation of competencies among students on Hospitality Industry specialty:

1. The use of cases only in the university environment is less efficient than in the framework of specific hotel enterprise.

2. There is a low interest of employers to participate in the development and validation of tests, carrying out interim and final assessment of students required to assess the level of managerial skills formation, as reflected in the respective professional standards.

3. In situations when few case technologies are used in the educational process of the university, considerable time is required to prepare teachers and students to work with cases.

The study can also make the following recommendations to improve the use of case management techniques for the formation of competencies for students on Hospitality Industry specialty:

1. It is required to use cases in all or most disciplines taught in the master's degree programs, ensuring the continuity of cases, the continuation of them from one discipline to another, taking into account the characteristics of each discipline curriculum.

2. We should pay particular attention to the use of case studies during the passage of students studying in a master's manufacturing practices, as under these conditions increases their effectiveness in terms of formation management skills, reflected in an appropriate professional standard

3. It is also important to organize the constant interaction of educational program managers and employers' representatives, as well as those who participated in the development of professional 's standards of hospitality in both cases the development and assessment of the level of formation of managerial skills, as reflected in the relevant professional standards.

Let us note the high degree of coherence of expert opinion, for summary and ranking of which coefficient of concordance was used, because of the major problems expressed by experts in terms of case technology use for forming management skills expressed concordance coefficient was 0.72 , the recommendations - 0.61 . The results indicate that the co-ordination of expert opinion is positive and consistent rankings can be used in practice, the recommendations submitted are necessary and relevant for the improvement of educational programs graduate in Hospitality Industry Specialty.

Thus, according to the results of the study it can be concluded that, during the it is more effective to use unstructured cases, the solution of which occurs with the group forms of students' work, including project work. 
It is recommended to use creative and structured case studies in all disciplines related to the management, as well as during the production practice of students.

\section{DISCUSSIONS AND CONCLUSION}

The study developed an evaluation method of administrative competence formation among university students using case-based technologies. This method takes into account the requirements of competences formation listed in both educational and professional standards of business leaders. Research has proven the effectiveness of the proposed method due to the high correlation of the research results carried out in different institutions and different experts - teachers of universities and employers. Article materials may be useful for professionals who are responsible in the universities for the organization of educational work, as well as university professors, using casebased technologies for the formation of managerial skills among students.

\section{REFERENCES}

Anischeva, L. I. (2006). Akmeological concept development of innovative vocational education system. Voronezh. Publisher of the Voronezh State University.

Anufrieva, N. I. \& Tsarev, D. V. (2016). Social and Integrative Functions of a University Educational Environment in the Process of Music Students' Professional Competence Formation. Contemporary Problems of Social Work, 3(7), 134-141.

Cai, J., Youngblood, V. T., Khodyreva, E. A., \& Khuziakhmetov, A. N. (2017). Higher Education Curricula Designing on the Basis of the Regional Labour Market Demands. EURASIA Journal of Mathematics, Science and Technology Education, 13(7), 2805-2819.

Chen, F., Gorbunova, N. V., Masalimova, A. R., \& Bírová, J. (2017). Formation of ICT-Competence of Future University School Teachers. EURASIA Journal of Mathematics, Science and Technology Education, 13(8), 47654777.

Derkach, A. M. (2010). The case method in teaching. Specialist, 4, 22-23.

Ezechil, L. (2013). New Perspectives on Evaluation and Certifying the Competences of Higher Education Graduates. Procedia - Social and Behavioral Sciences, 76(15), 7-12.

Gerasimov, B. N. (2009). Intensive educational technology. Samara. Publisher of the Samara Institute of Business and Management.

Golubkova, O. N., Masalimova, A. R., \& Bírová, J. (2017). The Development of Sociocultural Competence in Future Translators via the Methodology of Culture-Oriented Interpretation of English Language Fictional Texts. Man In India, 97(14), 73-83.

Gray, B. J., Ottesen, G. G., Bell, J., Chapman, C., \& Whiten, J. (2007). What are the essential capabilities of marketers? Marketing Intelligence \& Planning, 25(3) 271-295.

Jackson, D., \& Chapman, E. (2012). Non-technical skill gaps in Australian business graduates. Education+ Training, $54(2 / 3), 95-113$

Jiang, L., \& Alexakis, G. (2017). Comparing students' and managers' perceptions of essential entry-level management competencies in the hospitality industry: An empirical study. Journal of Hospitality, Leisure, Sport E Tourism Education, 20, 32-46.

Johanson, M., Ghiselli, R., Shea, L. J., \& Roberts, C. (2011). Changing competencies of hospitality leaders: A 25-year review Journal of Hospitality Tourism Education, 23(3), 43-47.

Khrulyova, A. A., \& Sakhieva, R. G. (2017). Forming of Informational Culture as a Necessary Condition of the Level Raising of Higher Education. Man In India, 97(15), 211-225.

Krasikova, E. N. (2007). The case method as a didactic tool in terms of vocational training in high school. Bulletin of Stavropol State University. Series: Education, 53, 55-61.

Lebedeva, Yu. I. (2012). Pedagogical conditions of formation of administrative competence. VIII All-Russia scientific-technical conference of young scientists dedicated to the 155th anniversary of the birth of K. E. Tsiolkovskogo (pp. 118-121). Krasnoyarsk. Siberian Federal University.

Lizunkov, V., Marchuk, V., \& Podzorova, E. (2015). Identification of Criteria, Features and Levels of Economic and Managerial Competencies Development for Bachelors in Mechanical Engineering. Procedia - Social and Behavioral Sciences, 206(17), 388-393

Malysheva, T. V., Shinkevich, A. I., Kharisova, G. M., Nuretdinova, Y. V., Khasyanov, O. R., Nuretdinov, I. G., Zaitseva, N. A., \& Kudryavtseva, S. S. (2016). The sustainable development of competitive enterprises 
through the implementation of innovative development strategy. International Journal of Economics and Financial Issues, 6(1), 185-191.

Millar, M., Mao, Z., \& Moreo, P. (2010). Hospitality \& Tourism Educators vs. The Industry. A Competency Assessment Journal of Hospitality E Tourism Education, 22(2), 38-50.

Minniti, L. F. S., Melo Jr J. S. M., Oliveira R. D., \& Salles, J. A. A. (2017). The use of case studies as a teaching method in Brazil. Procedia - Social and Behavioral Sciences, 237, 373 - 377.

Mironova, M. D., Zaitseva, N. A., Larionova, A. A., Novikov, A. I., \& Borissova, A. A. (2017). The formation of key competencies of employees of the enterprises of service sphere, applying innovative management techniques. International Journal of Advanced Biotechnology and Research, 8(2), 660-666.

Nikitina, Y. I., Konyushenko, S. M., Kuzina, E. A., Afanasyeva, T. V., Kozhanova, T. M., Platonova, R. I., \& Mingazov R. H. (2015). Fundamentalization and professionalization of learning content under the competence approach. Journal of Sustainable Development, 8(3), 155-161.

Olkhovaya, T. A., Shukhmana, A. E., Nevolina, V. V., Amirova, L. A., \& Zaitseva, N. A. (2016). A Synergy-Based Approach through Developing Cross-Disciplinary Module. IEJME - Mathematics education, 11(3), 467-474.

Panfilova, A. P. (2003). Igrotehnichesky management. Interactive technologies for learning and organizational development personnel. Moscow. Knowledge.

Platonova, R. I., Golokova, V. S., Ammosova, L. I., Barkalova, N. V., Zorina, A. V., Vygodchikova, N. N., Turayev R. R., Shaidullina A. R., \& Chernova Y. A. (2016). The implementation of trans-disciplinary principle in the content of higher school students humanitarian training. International Review of Management and Marketing, $6(2), 46-50$.

Raven, J. (2000) The Raven's progressive matrices: change and stability over culture and time. Cognitive Psychology, $41(1), 1-48$.

Romanovtseva, O. V. (2016). The Competence Approach in Education. Contemporary Problems of Social Work, 4(8), 83-91

Shen, P., Gromova, C. R., Zakirova, V. G., \& Yalalov, F. G. (2017). Educational Technology as a Video Cases in Teaching Psychology for Future Teachers. EURASIA Journal of Mathematics, Science and Technology Education, 13(7), 3417-3429.

Song, T., Ustin, P. N., Popov, L. M., \& Mudarisov, M. M. (2017). The Educational Technology of Ethical Development for Students. EURASIA Journal of Mathematics, Science and Technology Education, 13(6), 20952110.

Sorikhina, V. P. (2015). Integration of the Students in Research Activities: Formulation of the Problem. Contemporary Problems of Social Work, 1(3). 48-54

Tambovkina, T. Y., \& Krakovskaya, O. C. (2013). Case technology as a means of formation of organizational and managerial competence of bachelors of linguistics. Herald of Baltic Federal University. Kant, 2, 114-120.

Tatur, Y. G. (2004). Competence in the structure of the quality of the model training. Higher education today, 3, 13 14

Tesone, D. V., \& Ricci, P. (2005). Job Competency Expectations for Hospitality and Tourism Employees. Journal of Human Resources in Hospitality \& Tourism, 4(2), 53-64.

Turik, L. I. (2012). Debate. Games, developing, educational technology. Phoenix: Rostov-on-Don.

Valeeva, R. A., \& Gafurov, I. R. (2017). Document Initial teacher education in Russia: connecting theory, practice and research. European Journal of Teacher Education, 40(3), 342-360.

Vasileva, E. A. (2015). The Place of Higher Professional Education and Continuing Professional Education in the System of Public Relations. Contemporary Problems of Social Work, 1(1), 194-196.

Yumatov, K. V., Kiriyanova, L. G., Yakimova, N. S., Zaitseva, N. A., Larionova, A. A., \& Korsunova, N. M. (2017)/ Problem-Based Learning Methods for Training Staff for Tourism and Hospitality Clusters. Eurasian Journal of Analytical Chemistry, 12(5b):803-812

Zaitseva, N. A., Efremova, M. Y., Larionova, A. A., Kurkina, N. R., \& Breusova, E. A. (2017). Management and evaluation of educational programmes in higher education based on the requirements of employers. Modern Journal of Language Teaching Methods, 7(2), 167-176.

\section{http://www.ejmste.com}

